\title{
NOTES
}

\section{Dependents' Pregnancy-Related Medical Benefits and the Pregnancy Discrimination Act}

Title VII ${ }^{1}$ of the Civil Rights Act of 1964 prohibits discrimination in employment on the basis of sex. In 1978, Congress amended Title VII $^{2}$ with the express purpose of reversing an earlier Supreme Court decision ${ }^{3}$, General Electric Co. v. Gilbert, ${ }^{4}$ in which the Court held that exclusion of pregnancy coverage from a disability-benefits plan did not constitute sex-based discrimination under Title VII. ${ }^{5}$ The Pregnancy Discrimination Act (PDA) 6 defines "sex" under Title VII to include pregnancy or pregnancy-related conditions, and thus establishes that discrimination in employment on the basis of pregnancy constitutes discrimination on the basis of sex.

I. 42 U.S.C. $\$ 82000$ e to 2000 e- 6 (1976). Section 703 provides in pertinent part:

(a) It shall be an unlawful employment practice for an einployer-

(1) to fail or refuse to hire or to discharge any individual, or otherwise to discriminate against any individual with respect to his compensation, terms, conditions, or privileges of einployment, because of such individual's race, color, religion, sex, or national origin; or

(2) to limit, segregate, or classify his einployees or applicants for employment in any way which would deprive or tend to deprive any individual of employment opportunities or otherwise adversely affect his status as an employee, because of such individual's race, color, religion, sex, or national origin.

42 U.S.C. $\$ 2000$ e-2(a)(1976).

2. 42 U.S.C. $\$ 2000$ (k) (Supp. IV 1980). See infra note 6 and accompanying text.

3. 123 CoNG. REC. 29,641 (1977) (remarks of Senator Bayh) ("This legislation was made necessary by an unfortunate decision rendered by the Supreme Court in the case of Gilbert $v$. General Electric [sic] ... ."). See, e.g., H.R. REP. No. 948, 95th Cong., 2d Sess. 2-3 (1978) reprinted in in 1978 U.S. CODE CONG. \& AD. NEws 4749 [hereinafter cited as HousE RePORT]; Legislation to Prohibut Sex Diserimination on the Basis of Pregnaney: Hearings on H.R. 5055 and H.R 6075 Before the Subcomm on Employment Opportunities of the House Comm on Education and Labor, 95th Cong., Ist Sess. 1 (1977) [hereinafter cited as House HeARINGs]; 123 Cong. REC. 7539 (1977) (remarks of Sen. Williams).

4. 429 U.S. 125 (1976).

5. See infra text accompanying notes 13-22.

6. 42 U.S.C. \& 2000e(k) (Supp. IV 1980). The Pregnancy Discrimination Act (PDA) provides in pertinent part:

The terms "because of sex" or "on the basis of sex" include, but are not limited to, because of or on the basis of pregnancy, childbirth, or related medical conditions; and women affected by pregnancy, childbirth, or related medical conditions shall be treated the same for all employment-related purposes, including receipt of benefits under fringe benefit programs, as other persons not so affected but similar in their ability or inability Id. to work. 
Although the PDA clearly prohibits pregnancy discrimination against female employees, there is confusion in the courts ${ }^{7}$ and among commentators $^{8}$ over the scope of the Act's coverage. The Courts of Appeals for the Fourth and Ninth Circuits have addressed this issue in recent cases $^{9}$ involving inedical plans that provide comprehensive coverage for spouses and dependents of employees but exclude or provide less coverage for spouses' and dependents' pregnancy-related disabilities. These courts have focused on whether the Act applies to feinale employees only. or extends to female dependents of male employees, and have reached opposite conclusions.

This note examines the language and legislative history of the PDA and concludes that the amendment applies to feinale employees only. ${ }^{10}$ Even though the Act does not reach pregnancy discrimination involving einployee spouses or dependents, however, the discrimination inay nevertheless be illegal under general Title VII case law, depending on the kind of insurance plan involved and the analytic framework the court uses to evaluate those plans. ${ }^{11}$

\section{BACKGROUND}

A. General Electric Co. v. Gilbert

In General Electric Co. v. Gilbert, ${ }^{12}$ feinale employees ${ }^{13}$ of the General Electric Company challenged the company's disability plan under

7. See infra note 9.

8. See, e.g., Wald, Judicial Construction of the 1978 Pregnancy Discrimination Amendment to Tille VII: Ignoring Congressional Intent, 31 AM. U.L. Rev. 591, 601 (1982) (the Act applies to dependents); Williams, Firing the Woman to Protect the Fetus: The Reconciliation of Fetal Protection With Employment Opportunity Goals Under Tille VII, 69 GEO. L.J. 641,682 (1981) (PDA provides that pregnancy rule is never neutral); Note, Employment Discrimination-"Sex Discrimination" Under Tüle VII includes Differential Treatment of Pregnancy Related Disabilities, 45 Mo. L. REv. 145, 151 (1980) (literal reading of PDA indicates exclusion of pregnancy from dependents' benefits unlawful); The Pregnancy Disability (sic] Act: Does It Protect All Women?, 5 WOMEN's L. REP. 1, 5 (June, 1982) (PDA applies only to employees).

9. Newport News Shipbuilding \& Dry Dock Co. v. EEOC, 667 F.2d 448 (4th Cir. 1982), rev'g 510 F. Supp. 66 (E.D. Va. 1981), cert. granted, 51 U.S.L.W. 3442 (U. S. Dec. 6, 1982) (No. 82-411); EEOC v. Lockhced Missiles \& Space Co., 680 F.2d 1243 (9th Cir. 1982).

This issue has also been addressed in a number of other jurisdictions. See EEOC v. Emerson Elec. Co., 539 F. Supp. 153 (E.D. Mo. 1982); United Teachers-Los Angeles v. Board of Educ., 29 Empl. Prac. Dec. (CCH) I 32,759 (C.D. Cal. Mar. 3, 1982); EEOC v. Joslyn Mfg. \& Supply Co., 524 F. Supp. 1141 (N.D. Ill. 1981), appeal filed, No. 82-1634 (7th Cir. 1982); Kansas Ass'n of Commerce \& Ind. v. EEOC, 22 Fair Empl. Prac. Cas. (BNA) 1343 (D. Kan. 1980).

10. See infra notes $49-76$ and accompanying text.

11. See infra notes $92-97$ and accompanying text.

12. 429 U.S. 125 (1976).

13. Gilbert imvolved a class action by employees and former employees who had been pregnant and were denied benefits. Id. at 128-29. 
Title VII. ${ }^{14}$ The plan provided employees nonoccupational sickness and accident coverage, but excluded coverage for pregnancy-related disabilities. Drawing on its earher equal protection analysis of a similar disability plan in Geduldig v. Aiello, ${ }^{15}$ the Supreme Court reasoned that plans excluding pregnancy-related disabilities affect two groupspregnant women and nonpregnant persons. ${ }^{16}$ Because one group is female but the other is inale and female, the Court found a "lack of identity between the excluded disability and gender." 17 The Court held, therefore, that the pregnancy classifications in General Electric's employee disability plan were not gender-based and were valid under Title VII.

The Court recognized that under either a Constitutional ${ }^{18}$ or a Title VII analysis, ${ }^{19}$ even a facially neutral distinction would be imper-

14. See infra note 19.

15. 417 U.S. 484 (1974). The Geduldig Court upheld the constitutionality of a California disability insurance program that excluded pregnancy-related disabilities from coverage. The plan, funded by employees, was mandatory for those privately employed and not otherwise covered by a private voluntary disability plan approved by the State. 417 U.S. at $486-87$. The Court held that the program did not violate the equal protection clause and that California had a "legitimate interest" in keeping the insurance program self-supporting, without increasing the employee contribution rate. 417 U.S. at 494-96.

16. Quoting from Geduldig v. Aiello, 417 U.S. 484 (1974), the Gilbert court stated:

This case is thus a far cry from cases like Reed $v$. Reed . . . and Frontiero v. Richardson . . . involving discrimination based upon gender as such. The California insurance program does not exclude anyone from benefit eligibility because of gender but merely removes one physical condition-pregnancy-from the list of compensable disabilities. While it is true that only woinen can become pregnant, it does not follow that every legislative classification concerning pregnancy is a sex-based classification like those considered in Reed . . . and Frontiero.

429 U.S. at 134 (citations omitted).

17. 429 U.S. at 135 (quoting Geduldig v. Aiello, 417 U.S. at 496 n.20).

18. Plaintiffs bringing a sex discrimination case under the fifth or fourteenth amendments must show either that the challenged classification is based overtly on gender or, if gender-neutral, that its adverse effect reflects invidious gender-based discrimination. Personnel Adm'r v. Feeney, 442 U.S. 256, 274 (1979); see also Washington v. Davis, 426 U.S. 229, 240 (1976). (The invidious quality of a law claimed to be discriminatory must ultimately be traced to a discriminatory purpose). See generally Erickson, Pregnaney Discrimination: An Analytical Approach, 5 Women's RTS. L. REP. 83 (1979); Thomas, Differential Treatment of Pregnancy in Employee Disability Benefit Programs: Title VII and Equal Protection Clause Analysis, 60 OR. L. REv. 249 (1981). In order to maintain a classification based on sex, the defendant inust show that the classification serves "inportant governinental objectives" and is "substantially related to the achieveinent of those objectives." Craig v. Boren, 429 U.S. 190, 197 (1976).

Because of the requirement of "state action" for bringing an action under the fifth or fourteenth amendments, employees in the private sector nonnally rely on Title VIl of the 1964 Civil Rights Act. Title VII applies to an einployer with 15 or more employees. In 1972, Congress amended Title VII to cover state goverament employees as well. See Wald, supra note 8, at 593 n.12.

19. There are several ways to prove a prima facie sex discrimination case under Title Vll. The first is to establish that a classification or practice is based on sex, resulting in "treatment of a person in a manner which but for that person's sex would be different." City of Los Angeles Dept. 
missible if "it were in fact a subterfuge to accoinplish a forbidden discrimination."20 The Court found no evidence, however, of a hidden intent to discriminate against woinen. Nor did the Court find sufficient disproportionate impact on women to support an inference of sex discrimination. ${ }^{21}$ Focusing on the risks included in the plan rather than on the risks excluded, the Court concluded that the plan was legal absent either proof that the plan discriminated against males or feinales in terms of "aggregate risk protection"22 or evidence that the plan benefited men more than women.

The following year, the Supreme Court again examined a disability plan that did not include pregnancy coverage. In Nashville Gas Co. v. Satty, ${ }^{23}$ the Court found the company's sick leave plan indistinguishable from that in Gilbert and, therefore, not a per se violation of Title VII. It held, however, that the company's policy of denying woinen on pregnancy leave their accumulated semority did violate section 703(a)(2) of Title VII. Unlike Gilbert, in which the employer refused to extend to women a benefit men do not receive, in Satty, the employer imposed a burden on woinen that men need not bear. ${ }^{24}$ The Satty deci-

of Water \& Power v. Manhart, 435 U.S. 702, 711 (1978); Phillips v. Martin Marietta Corp., 400 U.S. 542, 544 (1971) (violation of Title VII to have one policy for men and one policy for women with like qualifications).

-A practice can also be challenged under a "disparate treatment" theory. "Disparate treatment" occurs when an employer treats some employees less favorably than others. For example, refusing to hire or promote employees, because of their race or sex is "disparate treatment." Proof of discriminatory motive is necessary, although it can be inferred in some cases. International Bhd. of Teamsters v. United States, 431 U.S. 324, 335 (1977); see also Texas Dep't. of Comnunity Affairs v: Burdine, 450 U.S. 248 (1981) (appropriate analysis of disparate treatment case); McDonnell Douglas Corp. v. Green, 411 U.S. 792, 802 (1973) (proper burden of proof in disparate treatment case). See generally, Note, Evidentiary Burden of Proof in Tille VII Employment Discrimination Cases: Texas Dept. of Community Affairs v. Burdine, 24 How. L.J. 333 (1982). An employnent classification or practice, neutral on its face, can be challenged under Title VII if it lias a substantially adverse impact on a particular class. Under this theory, a plaintiff need not show intent, but must prove a significantly discriminatory effect. See generally Erickson, supra note 18 , at 11 .

Once a prima facie case is established, the defendant must present a business necessity defense, indicating that the challenged practice or classification is related to job performance. Griggs v. Duke Power Co., 401 U.S. 424, 431 (1971); see Dothard v. Rawlinson, 433 U.S. 321 (1977) (disparate impact analysis of Griggs and Albemarle applies to sex discrimination cases); Albemarle Paper Co. v. Moody, 422 U.S. 405 (1975) (procedure for establishing disparate impact). See generally 1 A. LARSON, EMPLOYMEnt Discrimination $\$ 811.00-12 A .50$ (1981).

20. 429 U.S. at 136; see supra note 19 (proving intent).

21. 429 U.S. at 138-39. See supra note 19 (imferring sex discrimination from disparate impact).

22. 429 U.S. at 138.

23. 434 U.S. 136 (1977).

24. 434 U.S. at 142. In Satty, only employees taking a leave of absence because of pregnancy lost their seniority rights. Other inale and female employees, taking leave for nonpregnancy-related disabilities, retained their accumulated seniority. 
sion, although indicating that in some instances pregnancy classifications are unlawful, left unclear when courts ought to apply the Satty benefit-burden test. ${ }^{25}$ In the face of such uncertainty and the unacceptable holding of Gilbert, ${ }^{26}$ Congress passed the Pregnancy Discrimination Act in 1978.

\section{B. The Courts of Appeals' Decisions}

Congress enacted the PDA to clarify the definition of sex discrimination under Title VII. The PDA specifies that sex discrimination includes discrimination "on the basis of pregnancy, childbirth, or related medical conditions." 27 Although the Act requires einployers to treat womcn "affected by pregnancy" the same for all "employment-related purposes" as they would other disabled einployees, ${ }^{28}$ it is not limited expressly to female employees. Therefore, somc courts have interpreted the Act as prohibiting differential treatnent of the pregnancy-related conditions of employee dependents. The Court of Appeals for the Fourth Circuit, in the broadest imterpretation of the Act to date, held that if an insurance plan provides full coverage for spouses of female eniployees, it nust provide similar coverage for the pregnancy-related expenses of spouses of male eniployees. ${ }^{29}$ Conversely, the Court of Appeals for the Ninth Circuit held that the language and legislative history of the PDA limit the scope of the Act to feniale employees, ${ }^{30}$ and thus concluded that a plan excluding pregnancy-related health benefits for dependents does not violate Title VII.

1. Newport News Shipbuilding \& Dry Doek Co. v. EEOC. ${ }^{31}$ In Newport News, the Court of Appeals for the Fourth Circuit analyzed a

25. House RePORT, supra note 3, at 3. Under the Satty benefit-burden tesh, although employers were not required to provide benefits such as pregnancy coverage to their female employees, they could not burden women by depriving them of employment opportunities, 434 U.S. at 142, such as withdrawing the accumulated seriority of women on pregnancy leave.

26. See S. REP. No. 331, 95th Cong., lst Sess. 2-3 (1977) [heremafter cited as Senate REPORT]. 3.

27. 42 U.S.C. \& 2000e(k) (Supp. IV 1980); see supra note 6; SENATE REPORT, supra note 26, at

28. According to the Senate Report, "[p]regnant women who are able to work must be permitted to work [under] the same conditions as other employees; and when they are not able to work for medical reasons, they must be accorded the same rights, leave privileges and other benefits, as other workers who are disabled from working." SENATE REPORT, supra note 26, at 4.

29. Newport News Shipbuilding \& Dry Dock Co. v. EEOC, 667 F.2d 448 (4th Cir. 1982); eccord United Teachers - Los Angeles v. Board of Educ., 29 Empl. Prac. Dec. (CCH) I 32,759 (C.D. Cal. 1982).

30. EEOC v. Lockheed Missiles \& Space Co., 680 F.2d 1243 (9th Cir. 1982); accord EEOC v. Emerson Elec. Co., 539 F. Supp. 153 (E.D. Mo. 1982); EEOC v. Joslyn Mfg. \& Supply Co., 524 F. Supp. 1141 (N.D. Ill. 1981), appeal filed, No. 82-1634 (7th Cir. 1982).

31. 667 F.2d 448 (4th Cir.), cert. granted, 51 U.S.L.W. 3422 (U.S. Dec. 6, 1982) (No. 82-4111). 
health insurance plan that provided the full cost of hospitalization and a specified percentage of medical expenses for dependents of employees, but offered more limited hospital coverage for employees' spouses hospitalized for a routine pregnancy. ${ }^{32}$ The court examined the language of the PDA and concluded that the Act is not limited to female employees. Assuming that "women affected by pregnancy" can refer to spouses of male employees, ${ }^{33}$ the court decided that the "ability or inability to work" 34 language does not necessarily imply that the spouse "must be an employee of the employer providing the coverage." 35

Turning to the legislative history of the Act, the court referred to the remarks of Senators Bayh and Cranston. Both expressed the belief that pregnancy coverage could not be excluded from policies covering employee spouses. ${ }^{36}$ The court reasoned that, although the Senate Report left open the question of dependents' pregnancy benefits, the appropriate law to apply is Title VII as amended by the PDA.37 Interpreting the PDA as overruling both the specific holding of Gilbert and the reasoning on which it was based, the court observed: "Distinctions based on pregnancy the Congress said, are distinctions based on sex." 38 Therefore, the court found that a plan providing less complete coverage for married male employees than for married female employees discriminated on the basis of sex.

2. EEOC v. Lockheed Missiles \& Space Co. ${ }^{39}$ In Lockheed, the Court of Appeals for the Ninth Circuit examined a medical benefits plan that excluded from coverage expenses related to dependents' pregnancies. In interpreting the language of the PDA as limited to female employees, the court reasoned that, as a result of the amendment, the phrase "because of sex" in section 703(a)(1) includes "because of . . . pregnancy." 40 With that clarification in mind, the court read section 703(a)(1) to prohibit discrimination against "any individual with respect to his compensation . . . because of such individual's . . . preg-

\section{Id. at 449.}

33. When an employer considers extension of medical benefits to the spouses of employees, it does so with an "employment-related purpose" just as it does when it considers the extension of such benefits to employees. Benefits would never be extended to spouses if the extension did not serve an employment-related purpose.

667 F.2d at 450 .

34. See supra note 6.

35. 667 F.2d at 451. See infra text accompanying notes 54-59.

36. See 667 F.2d at 451 ; infra note 68 and text accoinpanying notes 69-70.

37. $667 \mathrm{~F} .2 \mathrm{~d}$ at 451 .

38. Id.

39. 680 F.2d 1243 (9th Cir. 1982).

40. 680 F.2d at 1245 . 
nancy. . .."4l The court concluded that this section could "hardly be read to apply to inale einployees. By choosing the definitional form of amendinent, Congress has expressly limited the scope of ... [the PDA] to women einployees." 42

The court found further support for its view in the Act's legislative history. Focusing on the Senate Report in which the Human Resources Committee stated that questions regarding dependents' pregnancy benefits should be determined "on the basis of existing Title VII primciples," 43 the court held that Congress expressly chose not to resolve the issue in the PDA, referring its resolution to the primciples established in case law ${ }^{44}$ and existing at the time the PDA was under consideration. Applying General Electric Co. v. Gilbert, the court then concluded that exclusion of pregnancy benefits to spouses of male employees is not gender-based discrimination. ${ }^{45}$

\section{The PDA: Language and Legislative History}

Both the Newport News and Lockheed courts construed the language and legislative history of the PDA to support their conflicting interpretations of the scope of the Act. However, careful examination of these areas supports the Lockheed court's refusal to apply the Act to dependents. The most obvious meaning of the statutory language limits its apphication to feinale einployees affected by pregnancy. ${ }^{46}$ Moreover, the legislative history of the PDA supports such a construction: 47 Congress passed the PDA to correct the damaging effects of the Gilbert decision on wolnen's employment opportunities, ${ }^{48}$ not to ensure pregnancy coverage for all wornen whether employed or not.

\section{A. Statutory Language.}

The PDA amended the definitional section of Title VII. The first clause of the Act states that "sex" as used in Title VII will now include "pregnancy" as a part of its ineaning. 49 Standing alone, the clause ap-

41. Id. (emphasis in original).

42. Id.

43. Id. at 1246. See infra text accompanying note 70.

44. 680 F.2d at 1246.

45. Id. at 1247.

46. See infra text accompanying notes 49-56.

47. See infra text accompanying notes 60-76.

48. See Discrimination on the Basis of Pregnancy, 1977: Hearings on S. 995 Before the Sub. comm on Labor of the Senate Comm on Human Resources, 95th Cong., Ist Sess. 21 (1977) (stateinent of Sen. Mathias) [hereinafter cited as Senate Hearungs].

49. 42 U.S.C. 882000 (k) (Supp. IV 1980); see supra note 6. 
pears to be broadly applicable to any pregnancy-based distinction. ${ }^{50}$ Because the PDA is included in the definitional section of Title VIl, however, the Court of Appeals for the Ninth Circuit appropriately read the clause in conjunction with section 703(a)(1): ${ }^{11}$ an einployer may not discriminate against any individual with respect to his compensation, terms . . . or privileges of employment, because of such individual's ... . sex. . . ."52 Because sex can be read to mean pregnancy under the PDA, the seemingly broad scope of the first clause is limited to einployees who are or will be pregnant. ${ }^{53}$

The second clause of the PDA furtlier indicates that the Act is limited to female employees by introducing a standard of comparability ${ }^{54}$ that can reasonably be understood only within the context of the employer-employee relationship: "women affected by pregnancy . . . shall be treated the same for all employment-related purposes . . . as other persons not so affected but similar in their ability or inability to work." 55 The plam meanings6 of the "ability to work" clause is that employers should treat pregnant workers as they do any other worker. The Newport News court argued, however, that "women affected by pregnancy" can refer to women who are not necessarily employees of the employer providing the coverage-for exaunple, employees' wives. ${ }^{57}$ But as the dissenting judge in that opinion noted, such an in-

50. It is a rule of statutory construction, however, that in order to determine the meaning of a clause, "one must proceed as he would with any other composition-construe it with reference to the leading idea or purpose of the whole instrument. . . [E]ach part or section should be construed in connection with every other part or section so as to produce a harmonious whole." $2 \mathrm{~A} \mathrm{~J}$. Sutherland, Statutory Construction $\$ 46.05$, at 56 (4th ed. 1973); see also Federal Power Comm'n v. Panhandle E. Pipe Line Co., 337 U.S. 498, 514 (1949). ("If possible, all sections of an act inust be reconciled so as to produce a symmetrical whole.").

51. See supra text accoinpanying notes 40-42.

52. 42 U.S.C. \& 2000e-2(a)(1976) (emphasis added); see supra note 1.

53. Employers may not discriminate against any "individual because of such individual's pregnancy." 680 F.2d at 1245 (emphasis in original).

54. In the Senate floor debates on the Amendment, Senator Cranston stated that its "basic standard is comparability among employees." 123 CoNG. REC. 29,663 (1977).

55. 42 U.S.C. \& 2000 e (Supp. IV 1980); see supra note 6. For example, if disabled workers are allotted a certain number of weeks of paid leave then pregnant workers ought to receive the same number if they are disabled by pregnancy. If sick workers receive hospitalization and medical costs for conditions not related to work, pregnant workers should receive the same benefits for their maternity costs. See Senate Report, supra note 25 , at 4.

56. See Caminetti v. United States, 242 U.S. 470, $485-86$ (1917) ("statutory words are uniformly presumed . . . to be used in their ordinary and usual sense, and with the meaning commonly attributed to thein"); see also Avery v. Commissioner, 292 U.S. 210, 214 (1924) (statutory words should be given ordinary meaning); United States v. Snider, 502 F.2d 645, 651 (4th Cir. 1974).

57. Congress probably did not use the more specific "employees" affected by pregnancy because Title VII applies to applicants for employinent and conceivably to terminated employees who are still entitled to benefit rights. 42 U.S.C. $\$ 2000$-2(a)(1976). See supra note 1. 
terpretation makes no sense alongside the comparability standard of the clause: "To determine whether a pregnant wounan is being treated the same as some other person who has the similar ability or mability to work, the pregnant woinan, by logical necessity, must also be an employee. To hold otherwise is simply to ignore the language of the Act."s8 Moreover, if Congress had intended that the PDA apply as broadly as the Newport News court suggests, Congress presumably would have protected "persons affected by pregnancy" and then indicated the appropriate comparability standard when female employees are pregnant. This langnage would cover male employees adversely affected by a dependent's pregnancy. Instead, Congress chose to limit the Act to "women affected by pregnancy." 59

\section{B. Legislative History.}

1. Objectives of the PDA. Congressional supporters of the PDA found the social implications of the Gilbert decision unacceptable. ${ }^{60}$ They reasoned that a central purpose of Title VII-to ensure the equality of women in the workplace-would be undermined if Gilbert were allowed to stand.61 As the House and Senate Reports emphasized, at the core of the sexual stereotypes that result in unfavorable treatment of women in employment is the employer's assuinption that woinen will eventually become pregnant and leave the labor market.62 Enployers who espouse such stereotypes view women as unrehable workers and are reluctant to give them jobs with responsibility. Sponsors of the PDA worried that Gilbert would allow employers to act on such stereotypes, thereby undermining the equal opportunity goals of Title VII.63 Thus, the PDA was introduced with the express purpose of providing "rehief" to the working women of America. ${ }^{64}$

58. 667 F.2d at 452.

59. See Brief for Appellee at 15, EEOC v. Joslyn Mfg. \& Supply Co., 524 F. Supp. 1141 (N.D. Ill. 1981), appeal filed, No. 81-1634 (7th Cir. 1982).

60. See, ag., Senate HeArngs, supra note 43, at 27 (statement of Sen. Kennedy) ("Recent setbacks in the. . . Supreme Court's decision in the Gilbert case mean that the Congress must be especially alert to ensure that its intent to halt sex discrimination is fully understood by the courts ... . .); 123 Cong. Rec. 29,641 (1977) (remarks of Sen. Bayh).

61. Senate Hearnos, supra note 48, at 1 (Gilberl constituted a "major setback" in the battle for women's rights and posed a serious threat to the development of anti-discrimination policies.); 123 CONO. REC. 7539 (1977).

62. HouSE REPORT, supra note 3, at 3; SENATE REPORT, supro note 26, at 3.

63. Because of Gilbert, employers would be free to force women to stop work because of pregnancy regardless of their ability to continue, refuse to hire or promote pregnant women, or otherwise limit their employment opportunities. SENATE REPORT, supra note 26, at 6.

64. 123 CONG. REC. 7540 (1977). 
The goal of the PDA was not to alter the basic principles of Title VII, but to clarify Congress's original intent in enacting that section of the Civil Rights Act. ${ }^{65}$ That original intent, explained in the Senate Report, was correctly expressed in the EEOC's 1972 Guidelines, which "inade clear that excluding applicants or einployees froin einployment because of pregnancy . . . was a violation of Title VII, and specifically required employers to treat disabilities caused . . . by pregnancy . . . as all other teinporary disabilities." 66 Thus, the PDA clarified original congressional intent by prohibiting discrimination against einployees on the basis of their pregnancy. The repeated references to "working woinen" and "the feinale workforce" made by the Act's sponsors ${ }^{67}$ and by those congressmen who addressed the bill in the floor debates are further evidence of Congress's intent to limit the reach of the Act to female einployees. ${ }^{68}$

2. The Question of Dependents' Benefits. The question of dependents' benefits arose during the Senate Committee hearings and floor debate on the amendinent. Senator Bayh, a sponsor of the PDA, offered his personal view that dependents should receive coverage:

While it is difficult to second-guess the courts, 1 feel that the history of sex discrimination cases under the 14th amendment in addition to previous interpretations of the Title VII regulations relating to the treatment of dependents will require that if companies choose to pro-

65. HOUSE REPORT, supra note 3, at 4.

66. SENATE REPORT, supra note 26, at 2. See generally Williams, supra note 8, at 673-74. The Gilbert Court rejected the EEOC's 1972 interpretation. 429 U.S. at 140-46 (1976).

67. See, e.g. 123 CoNG. Rec. 7540 (1977) (remarks of Sen. Williams) ("working women throughout our Nation from varied walks of life are in need of relief."); SENATE HEARINGS, supra note 48, at 5 (statement of Committee Chairman, Sen. Williams) (the issue before the committee is the recognition of working women as full and equal participants in the workplace); id. at 21 (stateinent of Sen. Mathias) (Gilbert posed "grave consequences for the female work force in America" which this legislation will counteract.); id. at 27 (statement of Sen. Kennedy) ("[T]he time has come for Congress to guarantee to the 39 million working women of this Nation that sex discrimination in employment is ended."); 123 CoNG. REC. 29,643 (1977) (remarks of Sen. Bayh) ("[F]orty-five percent of all married women are now in the work force, and this Nation owes these women equal protection under our laws.").

68. See, eg., 124 CoNG. Rec. 21,437 (1978) (remarks of Rep. Grcen) (This act "affords working-women the opportunity for comprehensive inedical protection which inen have . . . ."); id. at 21,439 (remarks of Rep. Quie) ("[T]his is necessary in order for wonen eniployees to enjoy equal treatment . . . "); id. (reunarks of Rep. Akaka) ("The bill simply requires that pregnant workers be fairly and equally treated."). As the Senate Report emphasized, the amendment was introduced to ensure that working women were protected agaimst employment discrimination; its basic principal was that "[p]regnant women who are able to work inust be permitted to work on the same conditions as other employees. . . when they are not able to work for medical reasons, they must be afforded the same rights . . . as other workers . . . " SENATE REPORT, supra note 26, at 3-4. Senator Cranston expressed his personal view that the Act should be construed to apply to dependents but admitted that the Senate Committee to which the bill was referred did not directly answer the question. 123 Cong. Rec. 29,663 (1977) (remarks of Sen. Cranston). 
vide full coverage to the dependents of their female employees, then they must provide such complete coveragc to the dependents of their male employees. 69

If the PDA reaches dependents, such unequal coverage would present a prima facie case of sex discrimination. That Senator Bayh did not mention this possibility suggests that he did not believe the PDA resolved the issue; rather, lee believed that dependent coverage is required by equal protection and Title VII standards as developed in case law.

The Senate Report on the PDA came to a similar conclusion:

Questions were raised in the committce's dehiberations regarding how this bill would affect medical coverage for dependents of employees, as opposed to employees themselvcs. In this contcxt it must be remembered that the basic purpose of this bill is to protect women employees; it does not alter the basic principles of Title VII law as regards sex discrimination. Rather, this legislation clarifies the definition of sex discrimination for Title VII purposes. Therefore the question in regard to dependents' benefits would be determined on the basis of existing Title VII principles. ${ }^{70}$

The Report underscored the basic purpose of the PDA-to protect female employees-but refused to apply the Act to pregnancy classifications that concerned noneinployees. Rather, questions involving the pregnancy coverage of dependents remain open, to be decided by the courts on an imdividual basis.

Cost estimates of the amendinent also suggest that the PDA was presented to Congress in terms of its application to woinen einployees. ${ }^{71}$ The committee discussions and floor debates over the economic impact of the Act focused on the cost of covering pregnant working women, not the cost of covering dependents. ${ }^{72}$ For example, when Senator Hatch asserted that the Act would benefit pregnant woinen, but males and nonpregnant woinen would bear a "substantial share" of

69. 123 CoNG. Rec. 29,642 (1977) (statement of Sen. Bayh).

70. Senate REPort, supra note 26, at 5-6.

71. In the Senate debates, Senator Bayh presented statistics on working women only. He concentrated on the rising number of working mothers in the U.S., and on the fact that $70 \%$ of them work because of economic hardship. 123 CONG. REC. 29,641 (1977); see also House REPORT, supra note 3 , at 9, in which the cost estimate of the Act refers only to employee coverage; House Hearings, supra note 3, at 101, 180-84 (Labor Dept. tables predicting birth rates and birth rates by industry for women workers).

Note, however, that cost estimates for health insurance were excluded because of difficulties in predicting future maternity expenses. If there were any indication in the cost estimates that the PDA extended to dependents, it wonld most likely appear in the health insurance tables rather than in those for disability benefits. A Congressman voting on the bill, however, was familiar with statistics on working women only.

72. See supra note 71; see also 123 CONG. REC. 29,642 (1977). 
the cost burden,"73 he obviously did not consider dependents' coverage; had the PDA reached dependents, males would not necessarily have been disproportionately burdened by the added cost because their wives would have been covered. It is reasonable to assume that other members of Congress similarly believed that the costs were projected in terms of only women employees.

Finally, in the Senate debates over the amendment, a revealing discussion took place between Senators Hatch and Williams concerning the dependents' benefits issue. ${ }^{74}$ In that colloquy, Senator Williams unequivocaly agreed that the PDA "only applies to the particular woman who is actually pregnant, who is an employee and has become pregnant after her einployment."75 Because Senator Williams was principal sponsor of the PDA, his remarks are "an authoritative guide to the statute's construction."76 Therefore, his unreserved assertion that the PDA reaches only employees should be afforded great weight in determining congressional intent concerning the scope of the Act.

\section{The EEOC Guidelines.}

The EEOC Guidelines 77 on the proper interpretation of the PDA contaim a "question and answer" section that includes a discussion of pregnancy coverage of dependents. ${ }^{78}$ The answer to question 21 states that if spouses of female employees receive medical coverage, then spouses of male employees must be afforded equal coverage, including coverage of pregnancy-related conditions. ${ }^{79}$ The standards the EEOC

73. 123 CONG. REC. 29,645 (1977) (statement of Sen. Hatch).

74. Mr. HATCH. [I]t is arguable that spouses of male employees are covered by this civil rights amendment. One might even argue that other female dependents are covered ....

I want to be sure that everybody knows from the record that it only refers to the woman employee who is pregnant or who becomes pregnant after her employment.

Mr. WILLIAMS. . . . I do not see how one can read into this any pregnancy other than that pregnancy that relates to the employee....

Mr. HATCH. So the Senator is satisfied that, though the committee language I brought up, "woman affected by pregnancy" seems to be ambiguous, what it means is that this act only applies to the particular woman who is actually pregnant, who is an employee and has become pregnant after her employment?

Mr. WILLIAMS. Exactly.

123 CONG. REC. 29,644 (1977).

75. Id.

76. North Haven Bd. of Educ. v. Bell, 102 S.Ct. 1912, 1921 (1982); see also Schwegmann Bros. v. Calvert Corp., 341 U.S. 384, 394-95 (1950) ("It is the sponsor that we look to when the meaning of the statutory words is in doubt.") See generally 2A J. SUTHERIAND, STATUTES AND STATUTORY CoNSTRuction § 48.15, at 221 (4th ed. 1973).

77. 29 C.F.R. $\$ 1604.10$ (1982).

78. 29 C.F.R. § 1604.10 \& app. (1982).

79. 21.Q. Must an employer provide health insurance coverage for the medical expenses of pregnancy-related conditions of the spouses of male employees? Of the dependents of all employees? 
used in answering question 21 are unclear, however. In the 1979 Introduction to the Guidelines, the Commission admitted that because the PDA did not "directly" resolve the dependents' benefits issue, it apphed "existing" Title VII principles in answering the question, ${ }^{80}$ but the Commission failed to specify whether those principles were based on Title VII case law as amended by the PDA, or on pre-PDA case law. ${ }^{81}$

Even if the EEOC applied the PDA ${ }^{82}$ in answering question 21, its conclusion is not dispositive. EEOC Guidelines are only interpretive rules meant to have the "power to persuade but lacking the power to control."83 Although at one time the Supreine Court viewed the agency as entitled to "great deference," 84 courts do not give much weight to the Guidelines ${ }^{85}$ when the rules are inconsistent with congressional intent. ${ }^{86}$ The EEOC's extension of the PDA to dependents appears to be inconsistent with considerable evidence of congressional intent to limit the scope of the Act to working women.87

A. [I]f an employer's insurance program covers the medical expenses of spouses of female employees, then it must equally cover the medical expenses of spouses of male employees, mcluding those arising from pregnancy-related conditions.

But the insurance does not have to cover the pregnancy-related conditions of other dependents as long as it excludes the pregnancy-related conditions of the dependents of male and female employees equally. 29 C.F.R. \& $1604 \&$ app. (1982).

80. 44 Fed. Reg. 23,804 (1979).

To the extent that a specific question is not directly answered by a reading of the Pregnancy Discrimination Act existing principles of Title VII must be applied to rcsolve that question. The legislative history of the Pregnancy Discrimination Act states explicitly that existing principles of Title VII law would have to be applied to resolve the question of benefits for dependents ....

The Commission, being responsible for interpreting and implementing Title VII, Id. utilized Title VII principles to arrive at the position reached on the dependent question.

81. See Comment, The Pregnancy Discrimination Act of 1978 and the EEOC Guidelines: A Return 10 "Great Deference?", 41 U. PITT. L. REv. 735, 754-55 (1980). The Lockheed court assumed that the EEOC's answer to question 21 was based on an erroneous interpretation of prePDA Title VII principles. 680 F.2d at 1246 n.3.

82. The Commission probably applied the PDA because in the dependents' benefits cases, see supra note 9, the EEOC has consistently argued that the PDA reaches dependents and requires pregnancy coverage of spouses of male employees.

83. General Elec. Co. v. Gilbert, 429 U.S. 125, 142-43 (1976) (quoting Skidinore v. Swift \& Co., 323 U.S. 134, 140 (1944)).

84. Griggs v. Duke Power Co., 401 U.S. 424, 434 (1971); see also Albemarle Paper Co. v. Moody, 422 U.S. 405, 431 (1975).

85. The Lockheed court rejected the Guidelines on the issue of extending the PDA to spouses because of the EEOC's "erroneous view of pre-existing Title VII principles." 680 F.2d at 1246 n.3; see also General Elec. Co. v. Gilbert, 429 U.S. at 140-42 (rejecting the 1972 EEOC Guidelines on pregnancy-related disabilities for employees).

86. Espinoza v. Farah Mfg. Co., 414 U.S. 86, $94-95$ (1973). See generally Comment, supro note 81 .

87. See supra text accompanying notes 61-76. 
Finally, the Supreme Court has specified certam factors to be considered when ascertaining the deference to be accorded agency interpretations. ${ }^{88}$ Among them are the thoroughness of the agency's consideration and the validity of its reasoning. ${ }^{89}$ In answering question 21, the EEOC failed to state the criteria on which it based its conclusions, ignored the potential conflict between its answer and congressional intent concerning the reach of the PDA, and neglected to explain what it meant by "existing Title VII principles." If the Guidelines were based on the Commission's interpretation of pre-PDA case law, the EEOC neither explained nor justified which aspects of the "meandermg course" 90 of sex discrimination law it chose to apply. Because of the uncertain basis on which the Commission formulated its answer and insufficient evidence to demonstrate a thorough consideration and careful reasoning of the critical issues involved, the EEOC's resolution of the spousal pregnancy issue should not be viewed as dispositive.

\section{Title VII Principles}

According to the Newport News court's interpretation of the PDA, Congress viewed all pregnancy classifications and not merely those affecting women employees as sex-based. ${ }^{91}$ The Court of Appeals for the Fourth Circuit understandably had difficulty limiting the reach of the PDA to female employees: under such a limitation, an employee's pregnancy disability is per se sex-based, but a dependent's pregnancy disability is not. The explanation for this ostensibly inconsistent treatment of the same disability is that the PDA focuses primarily on the employed woman affected by pregnancy, not on the risk of pregnancy itself. A pregnancy classification outside the scope of the PDA could nevertheless be successfully challenged under existing Title VII principles, using the analysis of General Electric Co. v. Gilbert. Although the PDA overruled the Gilbert Court's specific holding on the validity of excluding pregnancy coverage in an employee disability plan, the Gilbert analysis remains apphicable to cases of pregnancy exclusion not covered by the PDA.

\section{A. Establishing Sex Discrimination Under Title VII.}

To determine whether the pregnancy exclusion in General Electric's disability-benefits plan discriminated against female employees,

88. Skidmore v. Swift \& Co., 323 U.S. 134, 140 (1974).

89. Id.

90. Nashville Gas Co. v. Satty, 434 U.S. 136, 148 (1977) (Powell, J.; concurring).

91. 667 F.2d 448, 451 (4th Cir. 1982). 
the Gilbert Court rehed on the reasoning of Geduldig v. Aiello, ${ }^{92}$ which requires that the challenged plan affect one sex to the exclusion of the other. ${ }^{93}$ The Court noted that the affected and nonaffected groups in the General Electric disability plan were (1) pregnant woinen and (2) nonpregnant women and men. Because these groups are not exclusively identified with gender, the Court ruled that exclusion of pregnancy coverage in the disability plan was not gender-based. ${ }^{94}$

When the Ninth Circuit decided in Lockheed that the PDA does not reach dependents, it assumed that Gilbert established the validity of all pregnancy exclusions not covered by the PDA.95 Using a Gilbert analysis, however, it can be shown that some types of plans that exclude coverage of spousal pregnancies may discriminate against male employees.

For example, the medical insurance plan in Newport News fully covered the hospitalization of employees' dependents, but provided reduced coverage for the pregnancy-related hospitalization of employees' wives. In that situation, the two categories of employees to be compared would be married men and married women. ${ }^{96}$ Only married

92. 417 U.S. 484 (1974).

93. See City of Los Angeles Dep't of Water \& Power v. Manhart, 435 U.S. 702, 715 (1978) ("E]ach of the two groups of employees ... [must be] composed entirely and exclusively of members of the same sex.")

94. 429 U.S. at 135-36.

95. 680 F.2d at 1247 . .

96. In EEOC v. Emerson Elec. Co., the court examined a plan similar to that in Newport News. It followed the Gilbert analysis by dividing recipients into two groups-employees with pregnant spouses and employees without pregnant spouses. The court concluded that because the first group is exclusively male but the second is both male and female, the plan does not discriminate on the basis of sex. 539 F. Supp. 153, 158-59 (E.D. Mo. 1982). The court's groupings, however, do not adhere to the criterion for comparing groups under section 703 , that they be "similarly situated." See Willingham v. Macon Tel. Publishing, 507 F.2d 1084, 1088 (1975) (en banc), in which the court analyzed the standards for determining sex discrimination under Title VII ("has there been some form of discrimination, i.e., different treatment of similarly situated individuals . . . ."). To determine if a classification discriminates on the basis of spousal coverage, it follows that only married persons should be compared because the exclusion applies to them only.

Moreover, the Emerson Electric court's hiteral transplanting of the Gilbert categories-pregnant women and nonpregnant persons-produces anomalous results when applied to previous sex discrimination decisions. For example, in Phillips v. Martin Marietta Corp., 400 U.S. 542 (1971), the Supreme Court ruled that an employer may not refuse to hire women with pre-school-age children while hiring men with children of that age. If that decision were analyzed under the Gilbert and Emerson Electric groupings, women with pre-school-age children would be in the disfavored group while men and wounen without pre-school-age children would be in the favored group; thus no sex discrimination would be shown. The Supreme Court held, however, that Marin Marietta did discriminate on the basis of sex because "[s]ection 703(a) . . . requires that persons of like qualifications be given employment opportunities irrespective of their sex." 400 U.S. at 544. See also Sprogis v. United Airlines, 444 F.2d 1194 (7th Cir.), cert. denied, 404 U.S. 991 (1971) (illegal to refuse to hire married airline stewardesses while hiring married stewards) (under 
male employees would be in the disfavored group and only married female employees in the favored group because females would receive full coverage for spouses while male employees would not. Therefore, the plan could be shown to discriminate against males within the affected class of married persons. On the other hand, the Lockheed plan excluded all dependents from pregnancy coverage, creating a disfavored group of male employees whose wives and daughters are not covered and feinale employees whose daughters are not covered; the favored group consists of male and female employees whose dependents are incapable of becoming pregnant. Because the Lockheed groups do not divide along strict gender lines, the pregnancy exclusion does not, on its face, discriminate against males. Thus, under Gilbert, the validity of a pregnancy classification depends on the nature of the insurance program involved.

\section{B. Disparate Impact Analysis.}

Although a Gilbert-type analysis of the Lockheed plan indicates that its pregnancy classification does not discriminate along strict gender lines, case law provides another avenue of attack. A classification that is gender-neutral on its face violates Title VII if it has a substantially disproportionate impact on one sex. ${ }^{97}$ Even so, a plaintiff challenging a Lockheed-type plan may have difficulty in presenting a prima facie disparate impact case. Male employees are more likely to bear the cost of a wife's pregnancy than female einployees are for their dependent daughters' pregnancies only if the comparable employees each have the same number of dependents capable of becoming pregnant. That is, if a male employee has a wife and two sons and a female employee has a husband and a daughter, the likelihood of the male employee's bearing the cost of his wife's pregnancy is much greater than the female's bearing the cost for her daughter. ${ }^{98}$ If, on the other hand, the female employee has four daughters and the male employee has one wife, it is more difficult to assume that one bears a greater risk

literal Gilbert groupings, married stewardesses would be in unfavored group while stewards and unmarried stewardesses would be in favored group with no sex discrimimation shown). Thus, because of potentially anomolous results, it does not seein likely that the Gilbert court intended an exact transplantation of its categories. Rather, because Gilbert speaks generally to the comparative risks covered for male and female employees, 429 U.S. at 135, comparisons of those of "like qualifications" should include married women, who receive full protection for their spouses, and married men, who do not.

97. See supra note 19.

98. Coverage of dependents in employment plans typically includes spouses and children under a certain age (the Lockheed plan sets at 19 the maximum age for coverage of dependents, 680 F.2d at 1247). Thus, although a male employee risks bearing the cost of his wife's pregnancy during her entire fertile period, a female employee only risks the cost until her daughter is 19. 
of pregnancy costs. Moreover, because many male employees' wives work and may be covered under their own employers' benefit plan, the impact of the pregnancy exclusion is further lessened.

Even if a benefits plan could be shown to affect male and female employees differently, the Supreme Court's language in Gilbert suggests that it views analysis of the effects of a pregnancy exclusion with disfavor. ${ }^{99}$ In Gilbert, the Court analyzed only the risks included in the coverage, rather than the risks excluded, and found that as long as the financial benefits of a plan did not discriminate against a class in terms of aggregate risk protection, no Title VII discrimmatory effect is shown. ${ }^{100}$ Thus, an insurance package must be "worth more" to one sex than another, ${ }^{101}$ making a claim based on disparate impact nearly impossible to prove. A male employee would have to show that the financial benefits of a total insurance package are worth less to him than to a similarly situated female employee. Such a showing could be made through statistical evidence ${ }^{102}$ of total announts of benefits received, but it is highly unlikely that the exclusion of pregnancy coverage would reduce the benefits received by males to a level significantly below that received by female employees. ${ }^{103}$

Assuming that a plaintiff could show that the package resulted in unequal benefits, such a showing still might not be enough to establish a prima facie.case of Title VII sex discrimination. The Supreme Court has suggested that "[e]ven a completely neutral practice will inevitably have some disproportionate impact on one group or another. This Court has never held that discrimination must always be inferred from such consequences." 104 Although the Court has not identified the cir-

99. "The [insurance] 'package' . . . covers exactly the same categories of risk, and is facially nondiscriminatory in the sense that ' $t$ l] here is no risk from which men are protected and women are not. Likewise, there is no risk from which women are protected and men are not.' . . [G]ender-based discrimination does not result simply becanse an employer's . . . plan is less than all-inclusive." 429 U.S. at 138-39.

100. See 429 U.S. 125, 138-40 (1976). See generally Comment, Differential Treatiment of Pregnancy in Employment: The Impact of Gilbert and Nashville Gas Co. v. Safty, 13 HARv. C.R.-C.L.L. REv. 717, $729-34$ (1978).

101. 429 U.S. at 138.

102. Use of statistical evidence to prove disparate impact is common. See International Bhd. of Teamsters v. United States, 431 U.S. 324, 339 (1977) (statistical analyses serve an important role). Courts differ as to how great a disproportionate impact must be shown. See generally Note, Employment Discrimination-Plaintiff' Prima Facie Case and Defendant's Rebuttal in a Disparate Impact Case, 54 TUL L. REv. 1187, 1191 n.34 (1980).

103. Exclusion of pregnancy benefits for employees under the General Electric Plan did not result in female employees receiving significantly fewer benefits than males. In fact, evidence was presented in the district court that even when women were not covered for pregnancy, it cost the company more to insure an average female employee than a inale employec. 129 U.S. at 131.

104. City of Los Angeles Dep't of Water \& Power v. Manhar, 435 U.S. 702,710 n.20 (1978) (emphasis in original); see also Delta Airlines v Kramarsky. 485 F Supp 300.309 (S.D.N.Y 
cumstances under which discrimination will not be inferred, in Gilbert ${ }^{105}$ and Satty 106 it implied its disapproval of the disparate impact test when the classification is pregnancy and the issue involves benefits, rather than infringement on employment opportunities. In Gilbert, Justice Rehnquist wondered whether proof of a discriminatory effect was sufficient under section 703(a)(1), and whether a showing of intent to discriminate might be required.107 In Satty, the Court declined to decide whether section 703(a)(1) required intent, but reaffirned that the impact test was appropriate when applied to section 703(a)(2), which prohibits practices that deprive an individual of employment opportunities or otherwise affect his status as an employee. ${ }^{108}$ Even if the impact test remaims valid for a section 703(a)(1) challenge, proof of discriminatory impact will be difficult to sustain absent a showing that the insurance plan does not pose distimct employment disadvantages for one sex.

\section{CONCLUSION}

The language and legislative history of the PDA support the interpretation of the Court of Appeals for the Ninth Circuit that the Act is limited to female employees. There is strong evidence that Congress intended the legislation to protect working women from discrimination based on pregnancy, not to make all distinctions based on pregnancy a violation of Title VII.

Challenges to exclusions of pregnancy benefits for dependents, though outside the reach of the PDA, remain viable under existing Title VII principles. If a plaintiff can show that a particular healtlı plan

1980) (the Supreme Court has never adopted the view that an employment practice is illegal "simply" because it benefits members of one sex more than members of another) (emphasis from court), rev'd on other grounds, 650 F.2d 1287 (2d Cir. 1981).

105. 429 U.S. at 137.

106. 434 U.S. at 144.

107. 429 U.S. at 137. See infro note 108.

108. 434 U.S. at 144. Section 703(a)(1) of Title VII prohibits discrimmation with regard to compensation, terms, and privileges of employment; section 703(a)(2) prohibits practices that deprive an employee of employment opportunities or otherwise adversely affect his status as an employee. See supra note 1. Challenges to pregnancy classifications are usually brought under section 703(a)(1).

Justice Rehnquist's dicta implies that the intent requirement of the discrimination cases brought under the fourteenth amendment might be grafted onto a section 703(a)(1) challenge. Because intent is more difficult to prove, there has been some feeling that the Court is attempting to dilute the impact test. In his concurring opirion in Gilbert, Justice Blackmun refused to join the majority's imptication, if there was one, that the effects test was no longer good law. 429 U.S. at 146. Although other disparate effects cases do not mention a possible dilution of the test, see Williams, supra note 8, at 675, those cases do not concern a pregnancy classification. See generally Comment, Differential Treatment of Pregnancy, supro note 100, at 744-49. 
discriminates along strict gender lines, he can establish a prima facie case under Gilbert. If, on the other hand, a health plan excludes pregnancy coverage for all dependents, it is unlikely that Gilbert will permit a successful challenge. Not only would a plaintiff be unable to demonstrate strict gender groupings, he would also find it difficult to overcome the proof problems of disparate impact analysis created by the Supreme Court in Gilbert. A plaintiff's success depends, therefore, on the specific provisions of the challenged plan.

Gusti W. Frankel 